\title{
Activity-Guided Isolation of Antioxidant Principles from Limoniastrum feei (Girard) Batt.
}

\author{
Mehdi Chaabi ${ }^{\mathrm{a}, \mathrm{b}}$, Noureddine Beghidja ${ }^{\mathrm{b}}$, Samir Benayache ${ }^{\mathrm{b}}$, \\ and Annelise Lobstein ${ }^{\mathrm{a}, *}$ \\ a LC1 UMR-CNRS 7175, 'Biotechnologies, Biomolécules et Innovations Thérapeutiques', \\ Faculté de Pharmacie de Strasbourg, 78 route du Rhin, 67401 Illkirch, France. \\ Fax: +3 3390244310. E-mail: annelise.lobstein@pharma.u-strasbg.fr \\ b Laboratoire de Valorisation des Ressources Naturelles, Route Ain El-Bey, \\ 25000 Constantine, Algérie \\ * Author for correspondence and reprint requests \\ Z. Naturforsch. 63c, 801-807 (2008); received April 17/June 23, 2008
}

Bioguided fractionation of a leaves extract from Limoniastrum feei (Girard) Batt. (Plumbaginaceae) led to the isolation of seven polyphenolic constituents: gallic acid (1), myrciaphenone A (2), myricetin-3-O- $\beta$-galactopyranoside (3-1), epigallocatechin gallate (3-2), myricetin 3-O- $\alpha$-rhamnopyranoside (4), quercetin (5) and myricetin (6). Gallic acid was the most antioxidant compound in DPPH $[(0.94 \pm 0.68) \mu \mathrm{g} / \mathrm{mL}]$ and FRAP $\left[(0.83 \pm 0.15) \mu \mathrm{M} \mathrm{Fe} \mathrm{FL}^{2+} / \mathrm{mL}\right]$ tests, whereas myricetin was a more specific superoxide radical scavenger since it was the most active product in the superoxide nitroblue tetrazolium hypoxanthine/xanthine oxidase test $[(1.86 \pm 0.12) \mu \mathrm{g} / \mathrm{mL}]$.

Key words: Limoniastrum feei, Polyphenols, Oxidative Stress

\section{Introduction}

Plumbaginaceae is a cosmopolitan family which includes 836 species grouped in 27 genera. Only two of them, Limonium and Limoniastrum, are present in the Sahara (Ozenda, 2004). Limoniastrum feei (Girard) Batt. is a species endemic to Algeria and Morocco which can resist to extremely arid conditions (Quezel and Santa, 1963). A recent study revealed its good antibacterial activity (Belboukhari and Cheriti, 2005). However, to the best of our knowledge, no phytochemical studies have been conducted on the genus Limoniastrum until now.

Oxidative stress is caused by an imbalance in the oxidant/antioxidant equilibrium. Reactive oxygen species (ROS), generated either by endogenous or exogenous factors, are associated with the pathogenesis of various diseases such as inflammation, atherosclerosis, diabetes, cancer and arthritis (Halliwell and Gutteridge, 2000). During the past decade, interest in polyphenols, including flavonoids, has considerably increased due to the discovery of their various biological properties, principally their antioxidant effects and therefore their possible role in the prevention of several chronic diseases involving oxidative stress. Polyphenols inhibit cGMP and cAMP phosphodiesterases, xan- thine oxidase and elastase, for example (Plessi et al., 1998).

The aim of the present study was to assess the antioxidant activity of the semidesertic species $L$. feei, and to isolate its active consituents by bioguided fractionation using the 1,1-diphenyl-2-picrylhydrazyl $\left(\mathrm{DPPH}^{\bullet}\right)$ assay, an electron transfer (ET)-based method. The results were compared with those of two other complementary assays: FRAP (ferric reducing ability of plasma), another ET-based method, as well as the superoxide anion scavenging assay, a hydrogen atom transfer (HAT)based method.

\section{Material and Methods}

\section{Reagents and drugs}

All chemicals used were of at least analytical grade. 1,1-Diphenyl-2-picrylhydrazyl radical (DPPH) and 2,4,6-tri(2-pyridyl)-s-triazine (TPTZ) were obtained from Sigma Chemicals Co. (St. Louis, USA). Anhydrous sodium carbonate $\left(\mathrm{Na}_{2} \mathrm{CO}_{3}\right)$, cupric sulfate pentahydrate $\left(\mathrm{CuSO}_{4} \cdot 5 \mathrm{H}_{2} \mathrm{O}\right)$, ferric chloride hexahydrate $\left(\mathrm{FeCl}_{3} \cdot 6 \mathrm{H}_{2} \mathrm{O}\right)$, FolinCiocalteu phenol reagent, hydrochloric acid $(\mathrm{HCl})$, glacial acetic acid, methanol, and sodium acetate trihydrate were obtained from Merck 
(Darmstadt, Germany) and Neu reagent from Roth (Karlsruhe, Germany).

\section{Plant material}

The whole plant $L$. feei (Plumbaginaceae) was collected in Bechar region, in the southwest of Algeria, during the flowering stage in April 2003. It was identified by Prof. Khalfallah, Institute of Biology of Constantine, Algeria. A voucher specimen (LF98B0501) was deposited in the herbarium of University Mentouri of Constantine.

The dried plant material [309 $\mathrm{g}$ of leaves (L), $950 \mathrm{~g}$ of roots (R), and $1174 \mathrm{~g}$ of flowers (FL)] was exhaustively extracted with $80 \% \mathrm{EtOH}$ and then evaporated under reduced pressure to yield $25.5 \mathrm{~g}(8.2 \% \mathrm{w} / \mathrm{w}), 78.4 \mathrm{~g}(8.2 \% \mathrm{w} / \mathrm{w})$ and $181.4 \mathrm{~g}$ $(15.4 \% \mathrm{w} / \mathrm{w})$ of extracts, respectively (Table I).

Table I. Yield ( $\mathrm{g}$ ) of successive liquid/liquid extractions with solvents of increasing polarity of leaves (L), flowers $(\mathrm{FL})$, and roots ( $\mathrm{R})$.

\begin{tabular}{lrrr}
\hline Solvent & \multicolumn{1}{c}{$\mathrm{L}$} & \multicolumn{1}{c}{ FL } & \multicolumn{1}{c}{$\mathrm{R}$} \\
\hline $80 \%$ EtOH & 25.5 & 181.4 & 78.4 \\
$\mathrm{C}_{6} \mathrm{H}_{12}$ & 2.5 & 2.1 & 2.5 \\
$\mathrm{CH}_{2} \mathrm{Cl}_{2}$ & 1.2 & 4.7 & 4.5 \\
EtOAc & 4.2 & 10.2 & 7.3 \\
BuOH & 8.6 & 45.7 & 20.4 \\
\hline
\end{tabular}

\section{Extraction and bioguided fractionation}

Crude hydro-alcoholic extracts were extracted by liquid/liquid partition with solvents of increasing polarity: $\mathrm{C}_{6} \mathrm{H}_{12}, \mathrm{CH}_{2} \mathrm{Cl}_{2}$, EtOAc and finally $n$ $\mathrm{BuOH}$ (Fig. 1). The yield of each extract is reported in Table I. The comparison of their antiradical activity using the $\mathrm{DPPH}^{\bullet}$ test showed that the EtOAc leaves extract was the most active (Table II); thus, fractionation of the EtOAc leaves extract was pursued on a silica gel open column $(150 \mathrm{~g}$, mesh $60 \mathrm{~cm} \times 3 \mathrm{~cm})$ using stepwise gradient elution (50 mL/fraction): $\mathrm{C}_{6} \mathrm{H}_{12}(3 \mathrm{~L}) ; 1: 1(\mathrm{v} / \mathrm{v})$ $\mathrm{C}_{6} \mathrm{H}_{12} / \mathrm{CHCl}_{3}(1.5 \mathrm{~L}) ; \mathrm{CHCl}_{3}(2 \mathrm{~L}) ; 5 \% \mathrm{CHCl}_{3}$ in $\mathrm{MeOH}(400 \mathrm{~mL}) ; 10 \% \mathrm{CHCl}_{3}$ in $\mathrm{MeOH}(250 \mathrm{~mL})$; $15 \% \mathrm{CHCl}_{3}$ in $\mathrm{MeOH}(200 \mathrm{~mL}) ; 20 \% \mathrm{CHCl}_{3}$ in $\mathrm{MeOH}(300 \mathrm{~mL}) ; 30 \% \mathrm{CHCl}_{3}$ in $\mathrm{MeOH}(300 \mathrm{~mL})$; $40 \% \mathrm{CHCl}_{3}$ in $\mathrm{MeOH}(300 \mathrm{~mL})$; and finally $50 \%$ $\mathrm{CHCl}_{3}$ in $\mathrm{MeOH}(400 \mathrm{~mL})$. Fractions were combined according to their TLC profiles (silica gel $\mathrm{F}_{254} ; 5554$, Merck) using EtOAc/MeOH/ $\mathrm{H}_{2} \mathrm{O}$ $(100: 17: 13)(\mathrm{v} / \mathrm{v} / \mathrm{v})$ as eluent system. Plates were then revealed with NeuPEG (1\% methanolic di- phenylboric acid/ $\beta$-ethanolamino ester/polyethylene glycol) reagent and detected at 254 and $366 \mathrm{~nm}$ to afford 7 major fractions (Fig. 1). According to the antiradical activity of the seven fractions tested by the DPPH assay, purification was continued on fractions $80-196$ by means of semipreparative C18-HPLC, using $0.01 \mathrm{~m}_{3} \mathrm{PO}_{4}$ (phase A) and acetonitrile (phase B) as eluents. The elution was carried out under the following conditions: in $20 \mathrm{~min}$ from $5 \%$ to $50 \% \mathrm{~B}$, then in $5 \mathrm{~min}$ from $50 \% \mathrm{~B}$ to $100 \% \mathrm{~B}$. The fractions were monitored at $280 \mathrm{~nm}$ (UV detector, Gilson) (volume of injection: $400 \mu \mathrm{L}$ ). The purification afforded 6 subfractions which were controlled by analytical C18-HPLC. Thus, pure compounds obtained were $\mathbf{1}(157 \mathrm{mg}), \mathbf{2}(5 \mathrm{mg}), \mathbf{4}(496.8 \mathrm{mg}), \mathbf{5}$ $(4.7 \mathrm{mg})$ and $\mathbf{6}(20.4 \mathrm{mg})$. Subfraction 3 was further purified by Sephadex LH-20 column chromatography $(10 \mathrm{~g}, 30 \mathrm{~cm} \times 1.5 \mathrm{~cm})$ using $\mathrm{MeOH}$ $(200 \mathrm{~mL})$ as eluent and afforded compounds 3-1 (30 mg) and 3-2 (50 mg) (Fig. 1).

\section{Material}

The NMR spectra were recorded on Bruker DRX NMR (200 MHz and $300 \mathrm{MHz}$ ) spectrometers. Samples were dissolved in deuterated methanol $\left(\mathrm{CD}_{3} \mathrm{OD}\right)$. Mass spectroscopy was carried out on an Agilent LC/MSD instrument. Absorbances were measured in a Shimadzu UV 1205 spectrophotometer. Semipreparative C18-HPLC: pump, Gilson 305; UV detector, Gilson 115; column, Nucleodur $^{\circledR}$, Macherey-Nagel, $250 \times 21 \mathrm{~mm}, 10 \mu \mathrm{m}$. Analytical C18-HPLC: pump, Varian 9010; DAD UV detector, Varian Prostar $^{\circledR}$, Les Ulis, France; column Nucleodur ${ }^{\circledR}$, Macherey-Nagel, $250 \times 4.6 \mathrm{~mm}$, $5 \mu \mathrm{m}$. TLC: silica gel $\mathrm{F}_{254}$ (Merck), Sephadex LH20 (Sigma-Aldrich).

\section{Determination of total phenolic content (TPC)}

An aliquot of $100 \mu \mathrm{L}$ of extract was mixed with $2.5 \mathrm{~mL}$ of Folin-Ciocalteu phenol reagent and allowed to react for $5 \mathrm{~min}$. Then, $2.5 \mathrm{~mL}$ of saturated $\mathrm{Na}_{2} \mathrm{CO}_{3}$ solution were added and allowed to stand for $1 \mathrm{~h}$ before the absorbance of the reaction mixture was read at $725 \mathrm{~nm}$. The TPC of the extract was expressed as $\mathrm{mg}$ gallic acid equivalents per gram of plant material on dry weight basis (Parejo et al., 2002). 


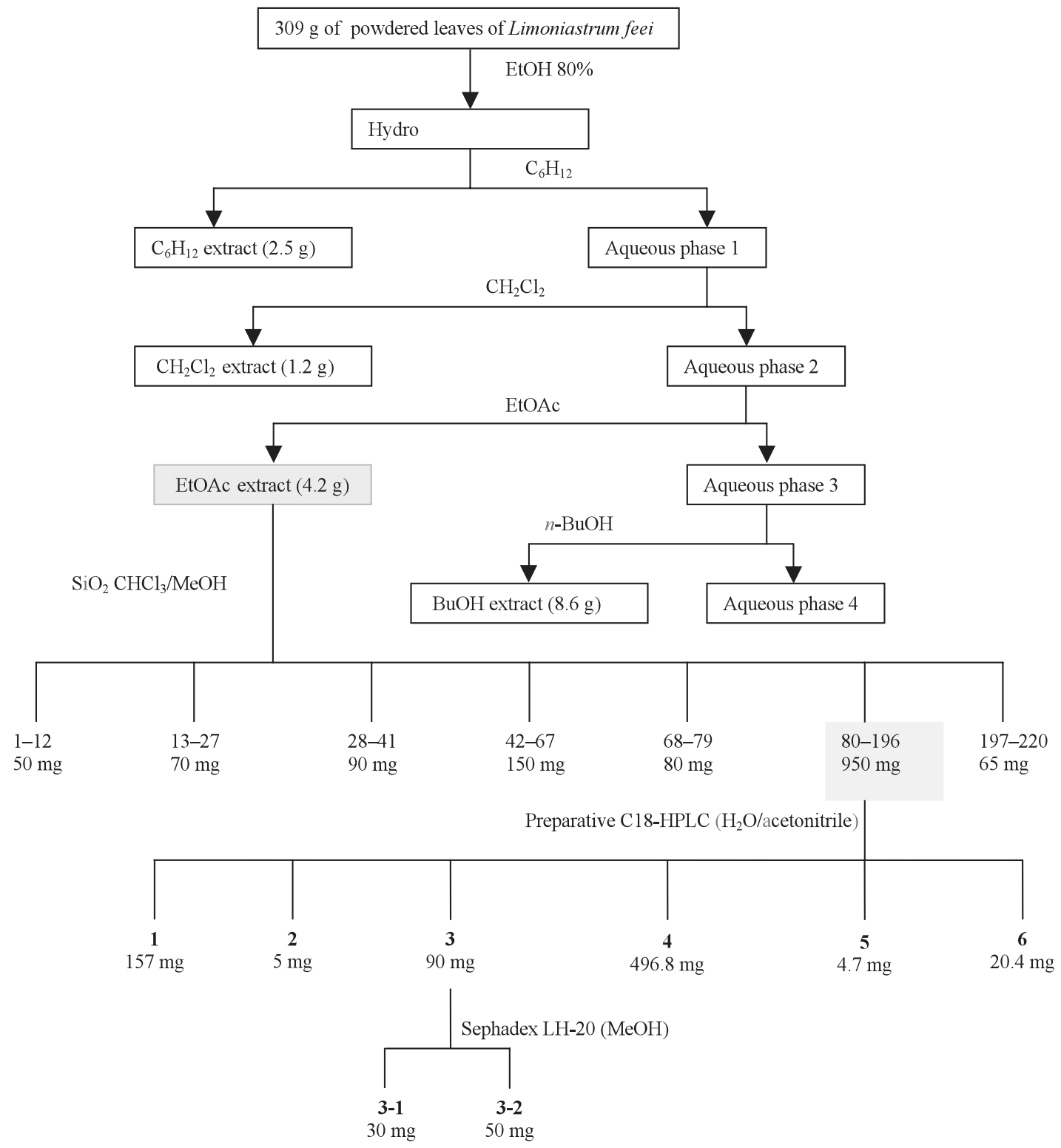

Fig. 1. Scheme of bioguided extraction and purification of $L$. feei EtOAc leaves extract. The same steps were followed to obtain different extracts of roots and flowers $\left(\mathrm{C}_{6} \mathrm{H}_{12}, \mathrm{CH}_{2} \mathrm{Cl}_{2}, \mathrm{EtOAc}\right.$ and $\left.\mathrm{BuOH}\right)$.

\section{Free radical scavenging activity}

The samples were measured in terms of hydrogen donating or radical scavenging ability using the stable radical $\mathrm{DPPH}^{\circ}$. The percentage of $\mathrm{DPPH}^{\bullet}$ decolouration of the sample was calculated according to the equation: \% decolourization $=\left[1-\left(A b s_{\text {sample }} / A b s_{\text {control }}\right)\right] \cdot 100$, where $A b s_{\text {sample }}$ is the absorption of the sample and
$A b s_{\text {control }}$ is the absorption of the blank without sample. Decolouration was plotted against the sample extract concentration, and a logarithmic regression curve was established in order to calculate the $\mathrm{IC}_{50}$ value, which is the amount of sample necessary to decrease the absorbance of $\mathrm{DPPH}^{\bullet}$ by $50 \%$ (Parejo et al., 2002). 


\section{Superoxide anion scavenging activity}

The superoxide radicals were generated in vitro by the hypoxanthine/xanthine oxidase system. The scavenging activity of the extract was determined by the NBT reduction method. In this method, $\mathrm{O}_{2}^{{ }^{-}}$reduces the yellow dye $\mathrm{NBT}^{2+}$ to produce the blue formazan, whose absorbance was measured spectrophotometrically at $560 \mathrm{~nm}$. Antioxidants are able to inhibit the formation of purple NBT. The results are expressed as the percentage inhibition of the NBT reduction with respect to the reaction mixture without a sample (buffer only) and were calculated according to the equation: \% inhibition $=\left\{\left[\left(C_{\mathrm{abs}}-C B_{\mathrm{abs}}\right)-\left(S_{\mathrm{abs}}-\right.\right.\right.$ $\left.\left.\left.S B_{\text {abs }}\right)\right] /\left(C_{\text {abs }}-C B_{\text {abs }}\right)\right\} \cdot 100$, where $S_{\text {abs }}, S B_{\text {abs, }}$, $C_{\text {abs }}$, and $C B_{\text {abs }}$ are the absorbance of the sample, the blank sample, the control, and the blank control, respectively (Parejo et al., 2002).

\section{Ferric reducing ability of plasma (FRAP)}

The ability to reduce ferric ions was measured using a modified version of a previously described method (Benzie and Strain, 1996). An aliquot $(200 \mu \mathrm{L})$ of an extract (with appropriate dilution, if necessary) was added to $3 \mathrm{~mL}$ of FRAP reagent (10 parts of $300 \mathrm{~mm}$ sodium acetate buffer at $\mathrm{pH}$
3.6, 1 part of $10 \mathrm{~mm}$ TPTZ solution and 1 part of $20 \mathrm{mM} \mathrm{FeCl} \cdot 6 \mathrm{H}_{2} \mathrm{O}$ solution), and the reaction mixture was incubated in a water bath at $37^{\circ} \mathrm{C}$. The increase in absorbance at $593 \mathrm{~nm}$ was measured after $30 \mathrm{~min}$. The antioxidant capacity based on the ability to reduce ferric ions of the extract was expressed as $\mu \mathrm{m}$ equivalent to $\mathrm{Fe}^{2+} / \mathrm{mL}$.

\section{Results and Discussion}

The comparison of the antiradical activities of crude hydro-alcoholic extracts of $L$. feei showed that the leaves (L) extract was 5- and 8-fold more active than the flower (FL) and root (R) extracts, respectively (Table II). In general, EtOAc extracts

Table II. Radical scavenging activities (DPPH test) of crude $80 \%$ EtOH extract along with $\mathrm{CH}_{2} \mathrm{Cl}_{2}$, EtOAc, $\mathrm{BuOH}$ extracts from roots (R), flowers (FL) and leaves (L) of Limoniastrum feei. Results are expressed as $\mathrm{IC}_{50}$ $(\mu \mathrm{g} / \mathrm{mL})$ values, mean $\pm \mathrm{SD}$ (standard deviation), of triplicate determinations.

\begin{tabular}{lrcc}
\hline Extract & $\mathrm{IC}_{50}(\mathrm{R})$ & $\mathrm{IC}_{50}(\mathrm{FL})$ & $\mathrm{IC}_{50}(\mathrm{~L})$ \\
\hline $80 \% \mathrm{EtOH}$ & \multicolumn{1}{c}{$3.3 \pm 1.43$} & $1.75 \pm 0.74$ & $0.38 \pm 0.06$ \\
$\mathrm{CH}_{2} \mathrm{Cl}_{2}$ & $44.04 \pm 12.37$ & $5.75 \pm 0.74$ & $8.67 \pm 4.49$ \\
$\mathrm{EtOAc}$ & $1.44 \pm 0.08$ & $1.63 \pm 0.32$ & $1.21 \pm 0.19$ \\
$\mathrm{BuOH}$ & $3.93 \pm 0.89$ & $2.82 \pm 0.24$ & $1.30 \pm 0.24$ \\
\hline
\end{tabular}

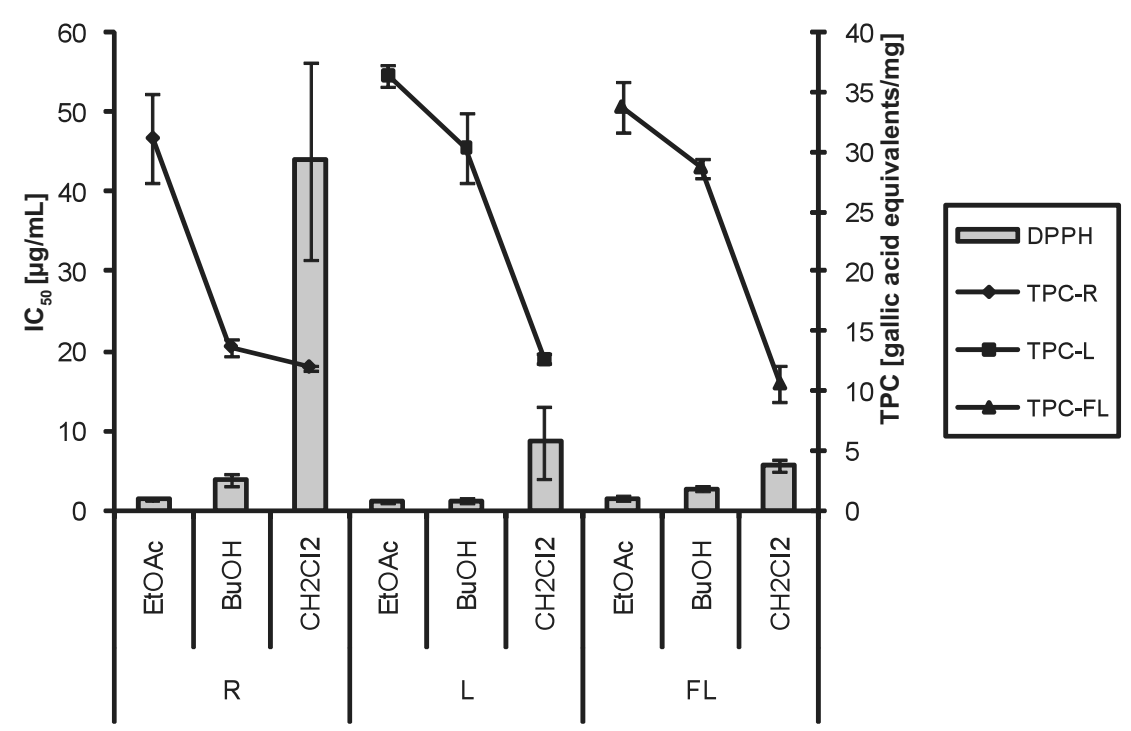

Fig. 2. Correlations between total phenolic content and antiradical activity of different extracts $\left(\mathrm{CH}_{2} \mathrm{Cl}_{2}, \mathrm{EtOAc}\right.$, $\mathrm{BuOH}$ ) obtained from roots, leaves and flowers of L. feei. TPC, total phenolic content (gallic acid equivalents/mg dry weight); DPPH assay expressed in $\mathrm{IC}_{50}(\mu \mathrm{g} / \mathrm{mL}) ; \mathrm{R}$, root extract $(R=0.6)$; L, leaves extract $(R=0.97)$; FL, flower extract $(R=0.99)$. 
were more active than $\mathrm{CH}_{2} \mathrm{Cl}_{2}$ and $\mathrm{BuOH}$ extracts (Table II), suggesting that they were more enriched in antiradical compounds. Indeed, TLC and HPLC profiles of EtOAc extracts of $\mathrm{L}$ and FL were quite similar and showed that they contain mainly flavonoids and phenolic acids (data not shown). These observations were strengthened by linear regression analysis of the antiradical activity and total phenolic content (Fig. 2). A good correlation between the antiradical effect and the total phenolic content of extracts $\left(\mathrm{CH}_{2} \mathrm{Cl}_{2}\right.$, EtOAc and $\mathrm{BuOH}$ ) was observed with $R=0.97$ and 0.99 for $\mathrm{L}$ and FL extracts, respectively, which suggests that polyphenols present in these extracts are responsible for the scavenging activity. However, there is a mild correlation between the phenolic content and the antioxidant activity in $\mathrm{R}$ extracts $(\mathrm{R}=0.6)$. Moreover, the excellent linear correlations between the "total phenolic profiles" and "the antioxidant activity" is not surprising if one considers similar chemistry of the two assays which are based on the electron transfer mechanism (Huang et al., 2005; Prior et al., 2005). Other studies have shown a high correlation between the total antioxidant activity and phenolic contents (Parejo et al., 2002; Guo et al., 1997).

Flavonoids are potent antioxidants in vitro, but antioxidation is, however, only one of the many mechanisms through which flavonoids can exert their actions (Erlund, 2004). Indeed, the actions ascribed to polyphenols are almost certainly mediated partly by their free radical scavenging, antioxidant and metal-complexing actions (Bahorun et al., 2004; Rice-Evans et al., 1996).

The anti-DPPH activity of the L. feei EtOAc leaves extract $\left[\mathrm{IC}_{50}=(1.21 \pm 0.19) \mu \mathrm{g} / \mathrm{mL}\right]$ was compared with that of corresponding extracts

Table III. Radical scavenging activities (DPPH test) of 7 major fractions obtained after silica gel fractionation of an EtOAc leaves extract. Results are expressed as $\mathrm{IC}_{50}(\mu \mathrm{g} / \mathrm{mL})$ values, mean $\pm \mathrm{SD}$ (standard deviation), of triplicate determinations.

\begin{tabular}{cc}
\hline Fractions & $\mathrm{IC}_{50}[\mu \mathrm{g} / \mathrm{mL}]$ \\
\hline $1-12$ & NS \\
$13-27$ & NS \\
$28-41$ & $30.93 \pm 17.84$ \\
$42-67$ & $9.07 \pm 2.47$ \\
$68-79$ & $18.35 \pm 4.42$ \\
$80-196$ & $1.74 \pm 0.13$ \\
$197-220$ & $1.44 \pm 0.09$ \\
\hline
\end{tabular}

NS, not significant $\left(\mathrm{IC}_{50}>100 \mu \mathrm{g} / \mathrm{mL}\right)$. prepared from some medicinal plants: Achillea millefolium, Artemisia dracunculus, Foeniculum vulgare, Lavandula latifolia, Melilotus officinalis $\left[\mathrm{IC}_{50}=(9.29 \pm 0.2) \mu \mathrm{g} / \mathrm{mL} ;(10.87 \pm 0.3) \mu \mathrm{g} / \mathrm{mL} ;\right.$ $(12.06 \pm 1.66) \mu \mathrm{g} / \mathrm{mL} ;(24.26 \pm 1.68) \mu \mathrm{g} / \mathrm{mL} ;(101.73 \pm$ 14.39) $\mu \mathrm{g} / \mathrm{mL}$, respectively] (Parejo et al., 2002), and highlighted that $L$. feei was far more active. Thus, activity-guided fractionation using the DPPH assay was continued on the EtOAc leaves extract, which gave 7 fractions, which were combined according to their TLC profiles (Fig. 1). These fractions were again tested for their antiradical power. Fractions $80-196$ were as active as fractions 197-220 (Table III) and possessed all the compounds of the latter fraction (data not shown). Furthermore, fractions 80-196 were 14-times in weight more than fractions 197-220 (Fig. 1); thus, purification was pursued on fractions $80-196$. The purification of the 6 major peaks of this fraction was carried out by semipreparative HPLC and Sephadex LH-20 chromatography and afforded 7 pure compounds (Fig. 1) identified by combined spectroscopic techniques (1D and 2D NMR, ESIMS, UV and co-injection with authentic standards) (copies of the original spectra are obtainable from the author of correspondence). These are gallic acid (1), myrciaphenone A (2), myricetin3-O- $\beta$-galactopyranoside (3-1), epigallocatechin gallate (EGCG) (3-2), myricetin 3-O- $\alpha$-rhamnopyranoside (4), quercetin (5) and myricetin (6) (Fig. 3). These polyphenolic compounds are encountered in different Limonium species like $L$. axillare (Ahmed et al., 1999; Bashir et al., 1994), L. brasiliense (Murray et al., 2004), L. wrightii (Aniya et al., 2002), and L. sinense (Lin and Chou, 2000). Thus, our results show a close chemotaxonomic relationship between Limonium and Limoniastrum.

The antioxidant activities of pure compounds were compared with the activities of the EtOAc extract and ascorbic acid taken as the reference antioxidant. Therefore, in the DPPH assay (Table IV), all compounds isolated, with the exception of 2, showed a potent antioxidant effect, where gallic acid was as active as the reference antioxidant $\left(\mathrm{IC}_{50}=0.94 \mu \mathrm{g} / \mathrm{mL}\right)$. In fact, compounds 1, 3-2 and $\mathbf{5}$ are routinely used as reference drugs in antioxidant tests (Erlund, 2004). In the same way, gallic acid was also the most active compound in the FRAP assay (Table IV); moreover, it was 2-fold more active than the reference compound ascorbic acid, but the other compounds 4-6 also had strong 
reducible power $\left(\mathrm{IC}_{50}<2 \mu \mathrm{g} / \mathrm{mL}\right)$. Another research team has found that gallic acid was the most active compound in DPPH and FRAP assays in comparison with other antioxidants (Schlesier et al., 2002). Some studies have indicated that phenolic substances, such as flavonoids and phenolic acids, are considerably more potent antioxidants than vitamins C and E (Cao et al., 1997; Vinson et al., 1995). Gallic acid (1) has been identified as the active compound of the water extract of Limonium wrightii with a strong free radical scavenging action (Bashir et al., 1994). It is noteworthy that gallic acid is the major compound in black tea (Hodgson et al., 2000). Black teas are also rich in EGCG, quercetin and myricetin (Ahmed et al., 2002; Luximon-Ramma et al., 2005). These compounds are well recognized as being responsible for the antioxidant properties of tea (Murray et al., 2004). In the superoxide scavenging activity assay (Table IV), unlike the two last tests, myricetin was the most antioxidant compound $\left(\mathrm{IC}_{50}=1.86 \mu \mathrm{g} /\right.$ $\mathrm{mL}$ ); it was 3-fold more active than ascorbic acid. Compounds 1, 3-5 were also a little or a lot more active than the reference vitamin $\mathrm{C}$.

Owing to the complexity of the oxidation/antioxidation processes, it is obvious that no single testing method is capable of providing a comprehensive picture of the antioxidant profile of a studied sample (Parejo et al., 2002; Prior et al., 2005). In addition, the total antioxidant capacity needs to reflect both lipophilic and hydrophilic capacity, and at least for physiological activity it needs to reflect and differentiate both the hydrogen atom transfer (radical quenching) and the electron transfer (radical reduction). Moreover, to fully elucidate its antioxidant capacity, tests evaluating the effectiveness against various reactive oxygen species (ROS)/reactive nitrogen species (RNS), such as $\mathrm{HO}^{\bullet}$ and $\mathrm{ONOO}^{\bullet-}$ are needed, and this may require future development of additional methods specific to each radical source (Prior et al., 2005).

In conclusion, Limoniastrum feei is a natural source rich in polyphenols (gallic acid, quercetin, myricetin and EGCG) possessing strong antioxidant activity, which could have a direct action on different diseases in relation with ROS/RNS.
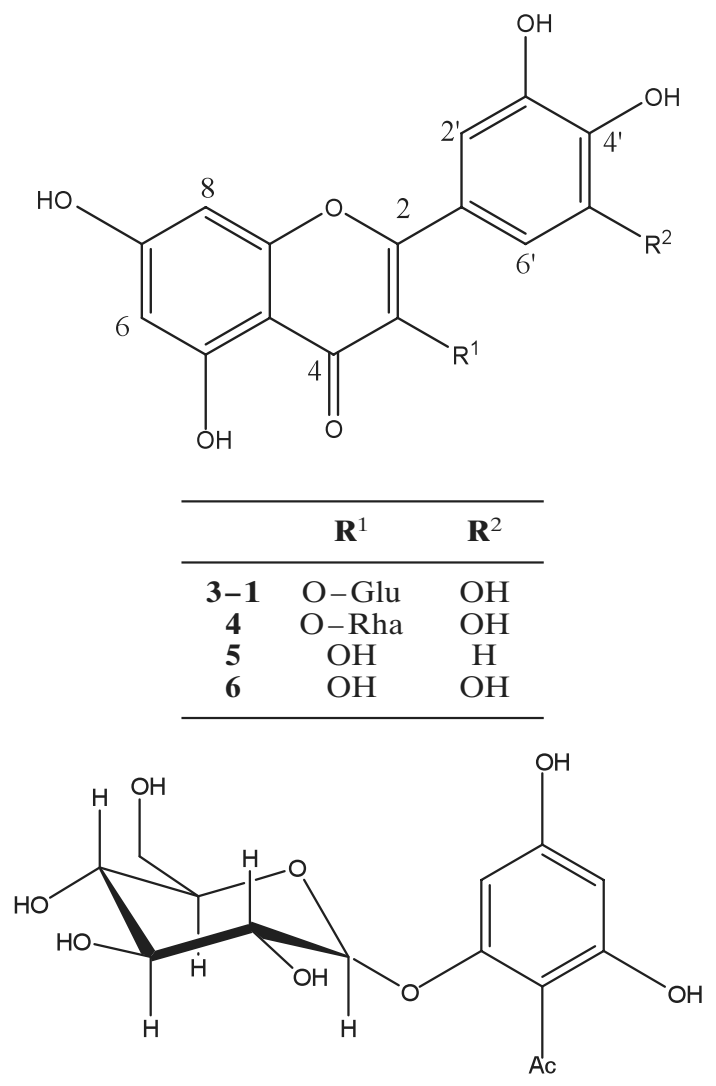

2<smiles>O=C(O[C@H]1Cc2c(O)cc(O)cc2O[C@@H]1c1cc(O)c(O)c(O)c1)c1cc(O)c(O)c(O)c1</smiles>

Fig. 3. Chemical structure of compounds 2-6. 


\begin{tabular}{lccc}
\hline Sample & \multicolumn{1}{c}{ DPPH $^{\mathrm{a}}$} & FRAP $^{\mathrm{b}}$ & Superoxide $^{\mathrm{a}}$ \\
\hline EtOAc extract & $1.21 \pm 0.19$ & $2.25 \pm 0.12$ & $3.61 \pm 0.56$ \\
Gallic acid (1) & $0.94 \pm 0.68$ & $0.83 \pm 0.15$ & $3.49 \pm 0.99$ \\
Myrciaphenone A (2) & $60.92 \pm 3.34$ & $7.61 \pm 1.68$ & $\mathrm{NS}>>10$ \\
Myricetin-3- $O$ - $\beta$ - & & & \\
$\quad$ galactopyranoside (3-1) & $2.84 \pm 0.69$ & $2.89 \pm 0.02$ & $2.85 \pm 0.2$ \\
Epigallocatechin gallate (3-2) & $2.54 \pm 0.45$ & $2.2 \pm 0.06$ & $2.1 \pm 0.08$ \\
Myricetin 3- $O$ - $\alpha-$ & & & \\
$\quad$ rhamnopyranoside (4) & $1.82 \pm 0.26$ & $1.38 \pm 0.39$ & $3.83 \pm 0.82$ \\
Quercetin (5) & $2.23 \pm 0.13$ & $1.48 \pm 0.19$ & $5.79 \pm 0.49$ \\
Myricetin (6) & $3.27 \pm 0.55$ & $1.60 \pm 0.14$ & $1.86 \pm 0.12$ \\
Ascorbic acid & $0.59 \pm 0.12$ & $1.62 \pm 0.62$ & $5.8 \pm 0.79$ \\
\hline
\end{tabular}

Table IV. Radical scavenging activities (DPPH, FRAP and superoxide) of 7 pure polyphenols purified by semipreparative C18-HPLC in comparison with their respective EtOAc extract. Results are expressed as mean \pm SD (standard deviation) of triplicate determinations.

\footnotetext{
a Values expressed as $\mathrm{IC}_{50}[\mu \mathrm{g} / \mathrm{mL}]$.

b Values expressed as EC1 in $\mu \mathrm{M}$ equivalent to $\mathrm{Fe}^{2+} / \mathrm{mL}$.
}

Ahmed K. M., Kandil F. E., and Mabry T. J. (1999), An anticancer tannin and other phenolics from Limonium axillare (Plumbaginaceae). Asian J. Chem. 11, 261263.

Ahmed S., Rahman A., Hasnain A., Lalonde M., Goldberg V. M., and Haqqi T. M. (2002), Green tea polyphenol epigallocatechin-3-gallate inhibits the IL-1 beta-induced activity and expression of cyclooxygenase- 2 and nitric oxide synthase- 2 in human chondrocytes. Free Radic. Biol. Med. 33, 1097-1105.

Aniya Y., Miyagi C., Nakandakari A., Kamiya S., Imaizumi N., and Ichiba T. (2002), Free radical scavenging action of the medicinal herb Limonium wrightii from the Okinawa islands. Phytomedicine 9, $239-244$.

Bahorun T., Luximon-Ramma A., Crozier A., and Aruoma O. I. (2004), Total phenol, flavonoid, proanthocyanidins and vitamin $\mathrm{C}$ levels and antioxidant activities of Mauritian vegetables. J. Sci. Food Agric. 84, $1553-1561$.

Bashir A. K., Abdalla A. A., Wasfi I. A., Hassan E. S., Amiri M. H., and Crabb T. A. (1994), Flavonoids of Limonium axillare. Int. J. Pharmacognos. 32, 366-372.

Belboukhari A. and Cheriti N. (2005), Antimicrobial activity of aerial part crude extract from Limoniastrum feei. Asian J. Plant Sci. 4, 496-498.

Benzie I. F. F. and Strain J. J. (1996), The ferric reducing ability of plasma (FRAP) as a measure of "antioxidant power": The FRAP assay. Anal. Biochem. 239, $70-76$.

Cao G., Sofic E., and Prior R. L. (1997), Antioxidant and prooxidant behavior of flavonoids: structure-activity relationships. Free Radic. Biol. Med. 22, 749-760.

Erlund I. (2004), Review of the flavonoids quercetin, hesperetin, and naringenin. Dietary sources, bioactivities, bioavailability, and epidemiology. Nutr. Res. 24, $851-874$

Guo C., Cao G., Sofic E., and Prior R. L. (1997), Highperformance liquid chromatography coupled with coulometric array detection of electroactive components in fruits and vegetables. Relationships to oxygen radical absorbance capacity. J. Agric. Food Chem. 45, $1787-1796$.

Halliwell B. and Gutteridge J. M. (2000), Free radicals and antioxidants in the year 2000. A historical look to the future. Ann. N. Y. Acad. Sci. 899, 136-147.

Hodgson J. M., Morton L. W., Puddey I. B., Beilin L. J., and Croft K. D. (2000), Gallic acid metabolites are markers of black tea intake in humans. J. Agric. Food Chem. 48, 2276-2280.

Huang D., Ou B., and Prior R. L. (2005), The chemistry behind antioxidant capacity assays. J. Agric. Food Chem. 53, 1841-1856.

Lin L. C. and Chou C. J. (2000), Flavonoids and phenolics from Limonium sinense. Planta Med. 66, 382-383.

Luximon-Ramma A., Bahorun T., Crozier A., Zbarsky V., Datla K. P., Dexter D. T., and Aruoma O. I. (2005), Characterization of the antioxidant functions of flavonoids and proanthocyanidins in Mauritian black teas. Food Res. Int. 38, 357-367.

Murray A. P., Rodriguez S., Frontera M. A., Tomas M. A., and Mulet M. C. (2004), Antioxidant metabolites from Limonium brasiliense (Boiss.) Kuntze. Z. Naturforsch. 59c, 477-480.

Ozenda P. (2004), Flore et végétation du Sahara. CNRS Editions, Paris, p. 566.

Parejo I., Viladomat F., Bastida J., Rosas-Romero A., Flerlage N., Burillo J., and Codina C. (2002), Comparison between the radical scavenging activity and antioxidant activity of six distilled and nondistilled Mediterranean herbs and aromatic plants. J. Agric. Food Chem. 50, 6882-6890.

Plessi M., Bertelli D., Rastelli G., Albasini A., and Monzani A. (1998), Fruits of Ribes, Rubus, Vaccinium and Prunus genus. Metal contents and genome. Fresenius' J. Anal. Chem. 361, 353-354.

Prior R. L., Wu X., and Schaich K. (2005), Standardized methods for the determination of antioxidant capacity and phenolics in foods and dietary supplements. J. Agric. Food Chem. 53, 4290-4302.

Quezel P. and Santa S. (1963), Nouvelle flore de l'Algérie et des régions désertiques méridionales. CNRS Editions, Paris, pp. 350-1170.

Rice-Evans C. A., Miller N. J., and Paganga G. (1996), Structure-antioxidant activity relationships of flavonoids and phenolic acids. Free Radic. Biol. Med. 7, 933-956.

Schlesier K., Harwat M., Böhm V., and Bitsch R. (2002), Assessment of antioxidant activity by using different in vitro methods. Free Radic. Res. 36, 177-187.

Vinson J. A., Dabbagh Y. A., Serry M. M., and Jang J. (1995), Plant flavonoids, especially tea flavonols, are powerful antioxidants using an in vitro oxidation model for heart disease. J. Agric. Food Chem. 43, 2800-2802. 